\title{
Renal- and calcium-dependent vascular effects of Polybia paulista wasp venom
}

Vinhote JFC (1), Torres AFC (2), Dantas RT (1), Praciano TP (2), Menezes RRPPB (1), Sousa DF (1), Brito TS (1), Lima FJB (1), Toyama MH (3), Magalhães PJ (1), Monteiro HSA (1), Martins-Nunes AMC (2)

(1) Department of Physiology and Pharmacology, Federal University of Ceará, Fortaleza, Ceará State, Brazil; (2) Department of Clinical and Toxicological Analyses, Federal University of Ceará, Fortaleza, Ceará State, Brasil; (3) São Paulo Experimental Coast Campus, São Paulo State University (UNESP - Univ Estadual Paulista), São Vicente, São Paulo State, Brazil.

\begin{abstract}
In the present study, the effects of Polybia paulista venom (PPV) on renal and vascular tissues were investigated. Isolated kidneys perfused with PPV (1 and $3 \mu \mathrm{g} / \mathrm{mL})$ had increased perfusion pressure, renal vascular resistance urinary flow, and glomerular filtration rate; and reduced sodium tubular transport. Histological evaluation demonstrated deposits of proteins in Bowman's space and tubular lumen, and focal areas of necrosis. The venom promoted a cytotoxic effect on Madin-Darby canine kidney (MDCK) cells. A significant increase in lactic dehydrogenase levels was observed in response to venom exposure. In isolated mesenteric vascular beds, pressure and vascular resistance augmented in a dose-dependent manner. PPV increased the contractility of aortic rings maintained under basal tension. This contractile response was inhibited when preparations were maintained in $\mathrm{Ca}^{2+}$-free medium. Likewise, verapamil, a voltage-gated calcium channel blocker, also inhibited the contractile response. In this study, phentolamine, a blocker of a-adrenergic receptor blocker, significantly reduced the contractile effect of PPV in the aortic ring. In conclusion, PPV produced nephrotoxicity, which suggests a direct effect on necrotic cellular death in renal tubule cells. The vascular contractile effect of PPV appears to involve calcium influx through voltage-gated calcium channels via adrenergic regulation.
\end{abstract}

Key words: Polybia paulista, venom, kidney, aorta, MDCK.

\section{INTRODUCTION}

In Brazil, there are several species of social wasps and little is known about the toxicological properties of their venoms. Many of these species, such as the neotropical wasp Polybia paulista, are involved in stinging incidents in urban areas in southeastern Brazil (1). The victims commonly describe severe pain and local inflammation, symptoms that reveal intense biological activity of P. paulista (PPV). Recently, a study reported hyperalgesic and edematogenic effects of peptides isolated from PPV (2). The constituents of PPV - such as melittin, apamin, phospholipases, hyaluronidases, acid phosphatases, proteases, nucleases, histamine and degranulating peptide mastoparan - are also reported to be components of Vespinae venoms, and have direct and indirect cytotoxic, hemolytic, neurotoxic and vasoactive properties (3-6).

Incidents involving these insects can be harmful, with a large number of patients, mainly allergic individuals, developing severe complications, including acute renal failure (ARF) $(7,8)$. It has been postulated that the underlying mechanism of ARF involves a direct nephrotoxic effect following wasp poisoning, which may then result in tubulointerstitial nephritis and acute tubular necrosis, possibly in association with hemolysis or rhabdomyolysis (9-14). In fact, 
mastoparans, polycationic peptides isolated from PPV, cause apoptosis involving caspase-signaling pathways with mitochondrial damage, and cytokine activation (15).

Despite the demonstration of the myotoxic effects of its constituents, the deleterious effects of PPV on kidneys have not yet been defined. Thus, the present study was designed to characterize the effects of PPV on renal and vascular tissues.

\section{MATERIAL AND METHODS}

\section{Animals}

Male Wistar rats (250-350 g) were maintained under standard conditions of temperature and humidity in 12-hour light-dark cycles. The animals were fasted for 24 hours before any experimental procedure and water was provided ad libitum. All experiments were in accordance with the guidelines for the ethical use of experimental animals published by the Brazilian College on Experimental Animal Care (COBEA), and experimental procedures were approved by the Institutional Animal Care Committee at Federal University of Ceará (protocol number 17/09).

\section{Venom and Reagents}

Polybia paulista wasp venom was kindly provided by Prof. M. H. Toyama of São Paulo State University (UNESP). All chemicals and analytical grade solvents were purchased from commercially available suppliers (Bayer, Sigma-Aldrich, Labtest Diagnostic and Applied Biosystems).

\section{Renal Effects Induced by PPV}

\section{Isolated rat kidney assay}

Rat kidneys were isolated and perfused according to the method described by Bowman (16) and modified by Fonteles et al. (17). Briefly, rats were anesthetized with sodium pentobarbital (50 mg/kg, intraperitoneally). The abdomen was opened through a midline incision, and the right kidney was exposed. After careful dissection of the kidney, the renal artery was cannulated via the mesenteric artery without interrupting blood flow. The perfusate solution consisted of a modified Krebs-Henseleit solution (MKHS) with the following composition in $\mathrm{mmol} / \mathrm{L}: 118.0$ $\mathrm{NaCl}, 1.2 \mathrm{KCl}, 1.18 \mathrm{KH}_{2} \mathrm{PO}_{4}, 1.18 \mathrm{MgSO}_{4} .7 \mathrm{H}_{2} \mathrm{O}$, $2.50 \mathrm{CaCl}_{2} .7 \mathrm{H}_{2} \mathrm{O}$ and $25.0 \mathrm{NaHCO}_{3}$. Six grams of bovine serum albumin (BSA) was added to $100 \mathrm{~mL}$ of MKHS and dialyzed for 48 hours at $4^{\circ} \mathrm{C}$ against 10 volumes of MKHS. Immediately before the beginning of each perfusion protocol, $100 \mathrm{mg}$ of urea, $50 \mathrm{mg}$ of inulin and $50 \mathrm{mg}$ of glucose were added to every $100 \mathrm{~mL}$ of perfusate, and the $\mathrm{pH}$ was adjusted to 7.4.

In each experiment, $100 \mathrm{~mL}$ of MKHS was recirculated for 120 minutes. Perfusion pressure (PP) was measured at the tip of a stainless steel cannula in the renal artery. Samples of urine and perfusate were collected at 10-minute intervals for the determination of sodium, chloride and potassium levels by means of ion-selective electrodes (Rapid Chem $744^{\oplus}$, Bayer Diagnostic, UK). Inulin was determined by direct hydrolysis, as described by Walser et al. (18) and modified by Fonteles et al. (17). Osmolality was measured using a vapor pressure osmometer (5100C, Wescor, USA). PPV (1 or $3 \mu \mathrm{g} / \mathrm{mL}$ ) was added to the system just after the basal perfusion pressure had stabilized (30 minutes after the beginning of each experiment). Perfusion pressure (PP), renal vascular resistance (RVR), urinary flow (UF), and glomerular filtration rate (GFR) were evaluated. Urine and perfusate samples were collected at 30-minute intervals to evaluate the percentage tubular transport for $\mathrm{Na}^{+}\left(\% \mathrm{TNa}^{+}\right), \mathrm{K}^{+}\left(\% \mathrm{TK}^{+}\right)$ and $\mathrm{Cl}^{-}\left(\% \mathrm{TCl}^{-}\right)$as determined by Pitts (19) and Martinez-Maldonato and Opava-Stitzer (20).

\section{Histological evaluation}

After completion of the experiment, the kidney was removed from the experimental setup and kept in 10\% formaldehyde for histological evaluation. Hematoxylin and eosin staining were used for light microscopy analysis.

\section{Cytotoxic effects induced by PPV}

Epithelial Madin-Darby canine kidney (MDCK) cells were cultured in RPMI-1640 medium, supplemented with FBS (10\%), penicillin $(100 \mathrm{U} / \mathrm{mL})$, and streptomycin $(100$ $\mu \mathrm{g} / \mathrm{mL}$ ). Cells were seeded at a concentration of $1 \times 10^{5}$ cells $/ \mathrm{mL}$ in microplates, and incubated at $37^{\circ} \mathrm{C}$ with $5 \% \mathrm{CO}_{2}$ for two hours. After cells were washed with sterile phosphate buffered solution (PBS) at pH 7.4, they were treated with PPV (3.12, $6.25,12.5,25,50$ or $100 \mu \mathrm{g} / \mathrm{mL}$ ) for 24 hours and then evaluated using an inverted microscope. The negative control was prepared with medium plus cells and PBS instead of venom. Before each 
experiment, cells were stored in medium without FBS for 24 hours to obtain cells in phase $G_{0}$ of the cell cycle (21).

\section{MTT assay}

MDCK cells were cultured as previously described, treated with PPV or PBS (negative control) and subjected to the MTT assay in microtiter plates after 24 hours of incubation. The supernatant of the cells was removed and 3-(4,5-dimethythiazol-2-yl)-2,5 diphenyltetrazolium (MTT) $(2.5 \mathrm{mg} / \mathrm{mL}$ in PBS; Sigma, Brazil) was added to each plate well (10 $\mu \mathrm{L} /$ well). The method is based on reduction of tetrazolium salt by active mitochondria in living cells to insoluble purple formazan crystals (22). After incubation for four hours at $37^{\circ} \mathrm{C}$ with $5 \%$ $\mathrm{CO}_{2}$, the supernatant was removed, and $10 \%$ sodium dodecyl sulfate (SDS) in $0.01 \mathrm{~N}$ HCL was added to solubilize the formazan crystals. The plates were incubated for 17 hours, and then absorbance was measured by spectrophotometry $(570 \mathrm{~nm})$. Cell viability was determined by evaluating the mean percentage of surviving cells at a given PPV concentration. Survival measured in the negative control was taken to be equal to $100 \%$.

\section{Lactate dehydrogenase (LDH) assay}

MDCK cells were cultured as previously described, treated with PPV or PBS (negative control) and subjected to the LDH assay in 96well plates after 24 hours of incubation. After treatment, $20 \mu \mathrm{L}$ of the supernatant was incubated with $1 \mathrm{~mL}$ of a solution of NADH $(2.5 \mathrm{mg} / \mathrm{mL}$ phosphate buffer) and pyruvate $(2.5 \mathrm{mg} / \mathrm{mL}$ phosphate buffer) (Labtest Diagnostics AS, Brazil). The rate of NADH oxidation was determined by measuring the decrease in absorbance at $340 \mathrm{~nm}$ for three minutes at 30 -second intervals at $25^{\circ} \mathrm{C}$ using a spectrophotometer.

\section{Vascular Effects Induced by PPV}

\section{Isolated perfused mesenteric bed}

Perfusion of the isolated mesenteric bed was carried out following the descriptions of McGregor (23). Briefly, Wistar rats were anesthetized with sodium pentobarbital (50 $\mathrm{mg} / \mathrm{kg}$, intraperitoneally). After opening the abdomen, pancreatic-duodenal, ileum-colic and colic branches of the superior mesenteric artery were tied. Then, the superior mesenteric artery was cleaned of surrounding tissue and cannulated with a polyethylene tube (PE20). The intestine was separated from the mesenteric bed by cutting close to the intestinal border of the mesentery. The mesenteric bed was perfused with Krebs solution containing: $\mathrm{NaCl} 114.0 \mathrm{mM}$; KCl $4.96 \mathrm{mM} ; \mathrm{KH}_{2} \mathrm{PO}_{4} 1.24 \mathrm{mM} ; \mathrm{MgSO}_{4} .7 \mathrm{H}_{2} \mathrm{O} 0.5$ $\mathrm{mM} ; \mathrm{NaHCO}_{3} 24.99 \mathrm{mM} ; \mathrm{CaCl}_{2} \cdot 2 \mathrm{H}_{2} \mathrm{O} 2.10 \mathrm{mM}$; and glucose $3.60 \mathrm{mM}$. The perfusion solution was kept warm at $37^{\circ} \mathrm{C}$, and the mesenteric bed was perfused using a constant flow rate $(4 \mathrm{~mL} /$ minute).

Changes in perfusion pressure were continuously measured with a pressure transducer (Statham P23, Gould, USA) and recorded using a four-channel physiograph (Narco BioSystems, USA). After the basal perfusion pressure had stabilized, the mesenteric vascular beds were perfused with Krebs solution containing PPV (3, 10 or $100 \mu \mathrm{g} / \mathrm{mL} ; \mathrm{n}=6)$ for ten minutes. Changes in the perfusion pressure of the mesenteric bed induced by PPV were compared to perfusion pressure recorded when preparations were perfused with vehicle alone at the same rate. Perfusion of the mesenteric bed with a solution of phenylephrine $(5 \mu \mathrm{M})$ for ten minutes was used as positive control.

\section{Aortic Ring Assay}

Male Wistar rats (250-300g) were sacrificed by stunning followed by cervical dislocation. Thoracic aortas were removed and immersed in perfusion medium at room temperature. After removal of adhering fat and connective tissue, aortas were cut transversally into cylindrical ringlike segments $(1 \times 5 \mathrm{~mm})$ and attached to steel wire triangular pieces $(0.3 \mathrm{~mm}$ diameter $)$, which were suspended in 5-mL organ baths containing Tyrode solution $(\mathrm{NaCl} 136 \mathrm{mM}$; $\mathrm{KCl} 5.0 \mathrm{mM}$;

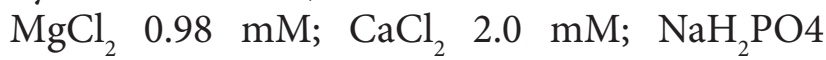
$0.36 \mathrm{mM} ; \mathrm{NaHCO}_{3} 11.9 \mathrm{mM}$ and glucose 5.5 $\mathrm{mM} ; \mathrm{pH} 7.4$ ) and continuously aerated at $37^{\circ} \mathrm{C}$. Endothelium-containing strips were stretched with a passive tension of $0.5 \mathrm{~g}$ - recorded using an isometric force transducer (Grass Model FTO3, USA) connected to a PC-based Dataq acquisition system (PM-1000,CWE Inc., Akron, USA).

After an equilibration period of at least 60 minutes, control contractions were induced by adding a submaximal concentration $(60 \mathrm{mM})$ of potassium chloride $(\mathrm{KCl})$ to the bath. When 
two successive control contractions showed similar amplitudes, preparations were considered equilibrated. To assess the effects of PPV, preparations were exposed during five-minute periods to increasing concentrations $(0.1 ; 0.3$; $1.0 ; 3.0 ; 10.0$; and $20.0 \mu \mathrm{g} / \mathrm{mL}, \mathrm{n}=4$ ) of PPV, which were directly added to the buffer solution in a cumulative manner. Contraction data were expressed as percentages of the potassiuminduced contraction. Concentration-effect curves were constructed by exposing the preparations to cumulatively increasing concentrations of $\mathrm{PPV}$ on basal tone in preparations maintained in $\mathrm{Ca}^{2+}$-containing medium, in $\mathrm{Ca}^{2+}$-free medium (containing $2 \times 10^{-5} \mathrm{M}$ EGTA), in the presence of verapamil $[10 \mu \mathrm{M}$, a well-know L-type voltageoperated $\mathrm{Ca}^{2}+$ channel (VOCC) blocker], and in presence of phentolamine $(5 \mu \mathrm{M})$, an $\alpha$-adrenergic blocker.

\section{Statistical Analysis}

Data are presented as means \pm SEM. The means were evaluated by Student's unpaired t-test and ANOVA, followed by the Bonferroni or Holm-Sidak test when appropriate. The level of acceptance for statistically significant differences was set at $5 \%(\mathrm{p}<0.05) . \mathrm{CI}_{50}$ values were estimated by curve interpolation as venom concentrations that resulted in $50 \%$ of cell inhibition, which correlates the mean percentages of dead cells and the venom concentration examined by non-linear regression analysis using GraphPad Prism 5.

\section{RESULTS}

\section{Effects of PPV on Isolated Perfused Kidney}

After basal perfusion pressure stabilized, rat kidneys were perfused for two hours with Krebs Henseleit solution containing either $1 \mu \mathrm{g} / \mathrm{mL}$ ( $\mathrm{n}$ $=6)$ or $3 \mu \mathrm{g} / \mathrm{mL}(\mathrm{n}=6)$ of PPV. Then, perfusion parameters were evaluated at 30-minute intervals (30, 60, 90 and 120 minutes). Treatment with PPV (3 $\mu \mathrm{g} / \mathrm{mL}$, but not with $1 \mu \mathrm{g} / \mathrm{mL}$ ) significantly increased ( $\mathrm{p}<0.05$; ANOVA-Bonferroni test) perfusion pressure (PP; Figure 1- A), renal vascular resistance (RVR; Figure $1-B$ ), urinary flow (UF; Figure 1 - C), and glomerular filtration rate (GFR; Figure 1 - D) when compared to control perfused kidneys. Table 1 shows the effect of PPV on electrolyte transport. PPV at 3 $\mu \mathrm{g} / \mathrm{mL}$ was also able to decrease sodium tubular transport $\left(\% \mathrm{TNa}^{+}\right) \quad(\mathrm{p}<0.05)$, but chloride $\left(\% \mathrm{TCl}^{-}\right)$and potassium $\left(\% \mathrm{TK}^{+}\right)$tubular transport were not changed.

Histological evaluation revealed moderate amounts of proteinaceous substances in the urinary spaces of kidney glomeruli and tubules
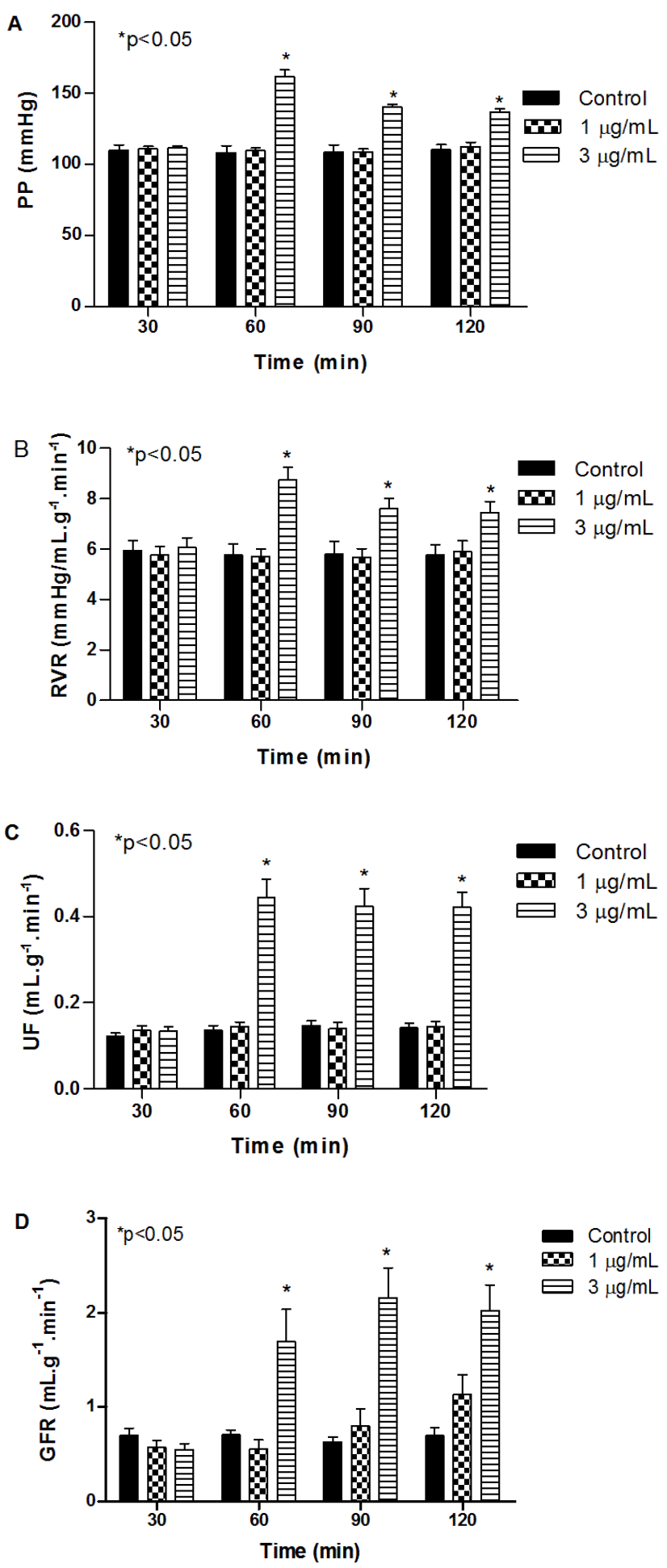

Figure 1. Effects of Polybia paulista venom (PPV; 1 and $3 \mu \mathrm{g} / \mathrm{mL}$ ) on: (A) perfusion pressure (PP), (B) renal vascular resistance (RVR), (C) urinary flow (UF) and (D) glomerular filtration rate (GFR) at various times. Values represent means $\pm \operatorname{SEM}(n=6)$. 
Table1. Effects of Polybia paulista venom ( $3 \mu \mathrm{g} / \mathrm{mL}$ ) on electrolytes transport in isolated kidney

\begin{tabular}{c|c|c|c|c}
\hline Renal parameters & 30 minutes & 60 minutes & 90 minutes & 120 minutes \\
\hline$\% \mathrm{TNa}^{+}$ & & & & \\
\hline Control & $80.66 \pm 1.09$ & $80.52 \pm 1.15$ & $80.52 \pm 1.06$ & $81.15 \pm 0.56$ \\
\hline Venom & $79.02 \pm 3.08$ & $68.00 \pm 4.00$ & $74.19 \pm 4.60$ & $72.35 \pm 5.10^{*}$ \\
\hline$\% \mathrm{TK}^{+}$ & & & & \\
\hline Control & $69.13 \pm 4.14$ & $69.04 \pm 5.68$ & $71.84 \pm 4.21$ & $69.94 \pm 6.86$ \\
\hline Venom & $62.62 \pm 3.62$ & $58.54 \pm 5.00$ & $71.48 \pm 5.00$ & $70.81 \pm 5.40$ \\
\hline$\% \mathrm{TCl}^{-}$ & & & & \\
\hline Control & $78.81 \pm 1.25$ & $80.18 \pm 2.90$ & $81.25 \pm 1.20$ & $80.49 \pm 2.47$ \\
\hline Venom & $71.84 \pm 3.66$ & $70.10 \pm 5.25$ & $73.35 \pm 5.39$ & $67.31 \pm 6.01$ \\
\hline
\end{tabular}

The results are expressed as the mean $\pm \mathrm{SEM}, \mathrm{p}<0.05$
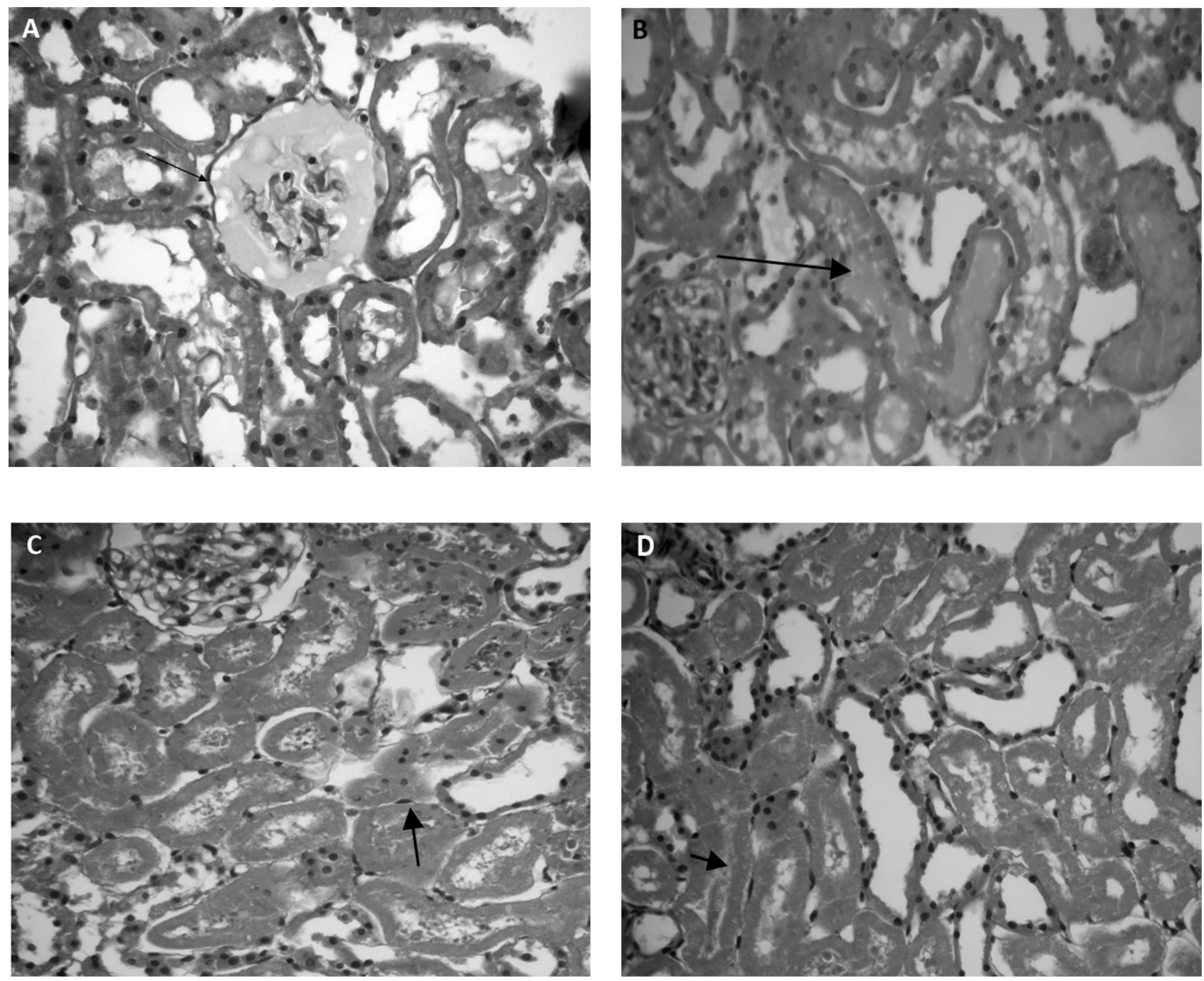

Figure 2. Photomicrograph of kidneys perfused with Polybia paulista venom (PPV) at a concentration of 3 $\mu \mathrm{g} / \mathrm{mL}$, which indicates (A) proteinaceous material in the urinary spaces and (B) tubules. Foci of necrosis, (C) nuclei and (D) cells without nuclei (hematoxylin-eosin, 400x). 
following treatment with PPV. Mild focal acute tubular necrosis was also observed in kidneys after PPV exposure (Figure 2). No changes were observed in control kidneys.

\section{Cytotoxic Effects of PPV on Renal Tubular Cells}

The cytotoxic effects of PPV in MDCK cells were analyzed by MTT and LDH assay. The venom promoted a concentration-dependent cytotoxic effect with an $\mathrm{CI}_{50}$ value of $25.81 \mu \mathrm{g} /$ $\mathrm{mL}$. Figure 3 shows the dose-response curve for MDCK cell viability after 24 hours of venom exposure and indicates significant decrease in cell viability for doses $\geq 25 \mu \mathrm{g} / \mathrm{mL}$ ( $\mathrm{p}<0.05$ ), as well as loss of membrane integrity accompanied by an increase in LDH activity.

\section{Effects of PPV on Isolated Perfused Mesenteric Bed}

Isolated perfused mesenteric beds had a perfusion pressure of $39.76 \pm 0.60 \mathrm{mmHg}$ after the stabilization period. When mesenteric preparations were subjected to $3 \mu \mathrm{g} / \mathrm{mL}$ of PPV perfusion for ten minutes, perfusion pressure was $39.87 \pm 0.80 \mathrm{mmHg}$, a value without statistical difference $(\mathrm{p}>0.05$, paired Student's t-test) compared to values before PPV treatment. Increases in perfusion pressure were observed when mesenteric preparations were perfused with PPV at concentrations higher than $3 \mu \mathrm{g} / \mathrm{mL}$. Perfusion pressure was significantly increased from $37.73 \pm 0.40 \mathrm{mmHg}$ before perfusion with
PPV to $43.10 \pm 1.77 \mathrm{mmHg}(\mathrm{p}<0.05$, paired Student's t-test) after perfusion with $10 \mu \mathrm{g} /$ $\mathrm{mL}$ of PPV and to $52.15 \pm 2.37 \mathrm{mmHg}$ ( $\mathrm{p}<$ 0.05 , paired Student's t-test) at $100 \mu \mathrm{g} / \mathrm{mL}$. As a positive control, phenylephrine $(5 \mu \mathrm{M})$ increased perfusion pressure values to $123.40 \pm 9.08 \mathrm{mmHg}$ (Figure 4).

\section{Effects of PPV on Isolated Aorta}

In endothelium-containing aorta preparations, PPV (0.1-20 $\mu \mathrm{g} / \mathrm{mL})$ induced contractile responses in a concentration-dependent manner ( $\mathrm{p}<0.001$; ANOVA-Holm-Sidak). The magnitude of the contraction induced by $20 \mu \mathrm{g} /$ $\mathrm{mL}$ of PPV corresponded to $135.7 \pm 14.6 \%$ ( $\mathrm{n}=$ 4) of a reference contraction induced by $60 \mathrm{mM}$ $\mathrm{K}^{+}(\mathrm{K} 60)$. In aortic rings maintained in $\mathrm{Ca}^{2+}$ free medium, the contractile effects induced by PPV were almost abolished and the magnitude of the maximal contraction was $7.5 \pm 1.2 \%$ of the K60 value $(\mathrm{n}=4 ; \mathrm{p}<0.05$; Figure $5-\mathrm{A})$, a value significantly lower than that observed in $\mathrm{Ca}^{2+}$-containing medium. Pretreatment of aortic rings with phentolamine $(5 \mu \mathrm{M})$ also significantly reduced PPV -induced contraction $(20 \mu \mathrm{g} / \mathrm{mL})$ to $48.9 \pm 16.0 \%$ of the K60 value $(\mathrm{n}=4 ; \mathrm{p}<0.05)$ (Figure $5-\mathrm{B}$ ). In order to evaluate the effect of a voltage-gated calcium channel blocker on PPVinduced contraction, preparations were treated with verapamil $(10 \mu \mathrm{M})$ and contractions elicited by PPV $(20 \mu \mathrm{g} / \mathrm{mL})$ significantly diminished to $24.6 \pm 10.6 \%$ of the K60 value ( $\mathrm{n}=4 ; \mathrm{p}<0.05$, ANOVA-Holm-Sidak) (Figure 5 - C).
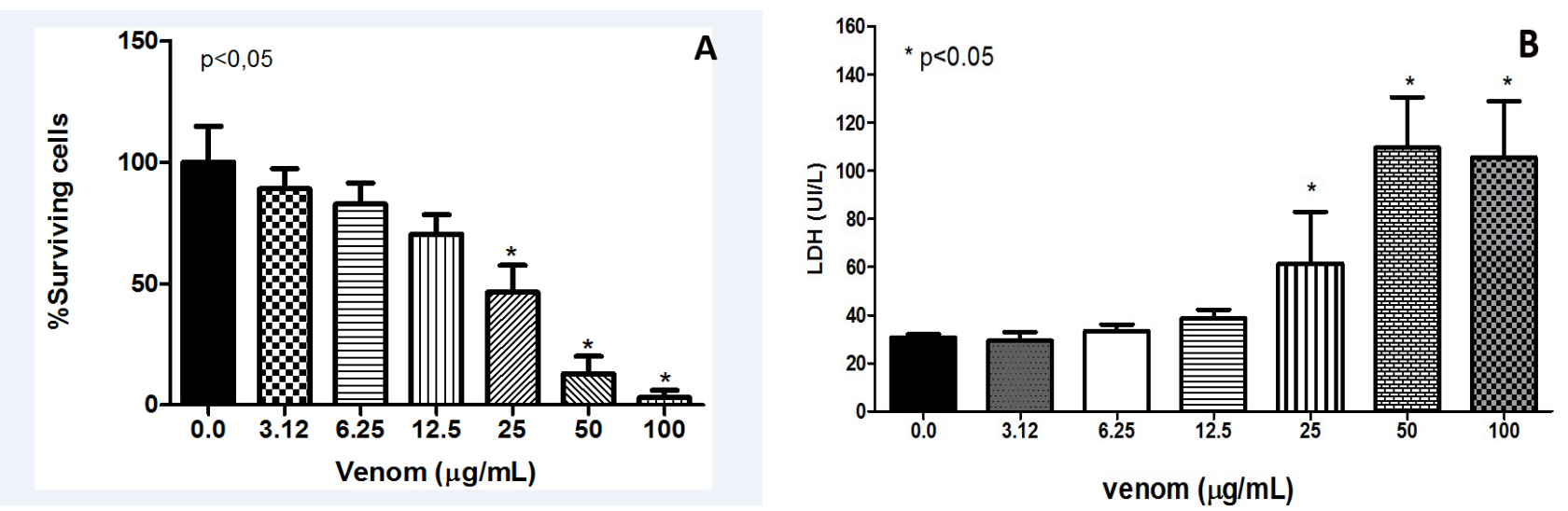

Figure 3. Cytotoxic effects of Polybia paulista venom (PPV; 3.12-100 $\mu \mathrm{g} / \mathrm{mL}$ ) on MDCK cells by (A) MTT and (B) lactic dehydrogenase assays. Data are expressed as means \pm SEM, ANOVA, Bonferroni post-test, ${ }^{*} \mathrm{p}<0.05$. 

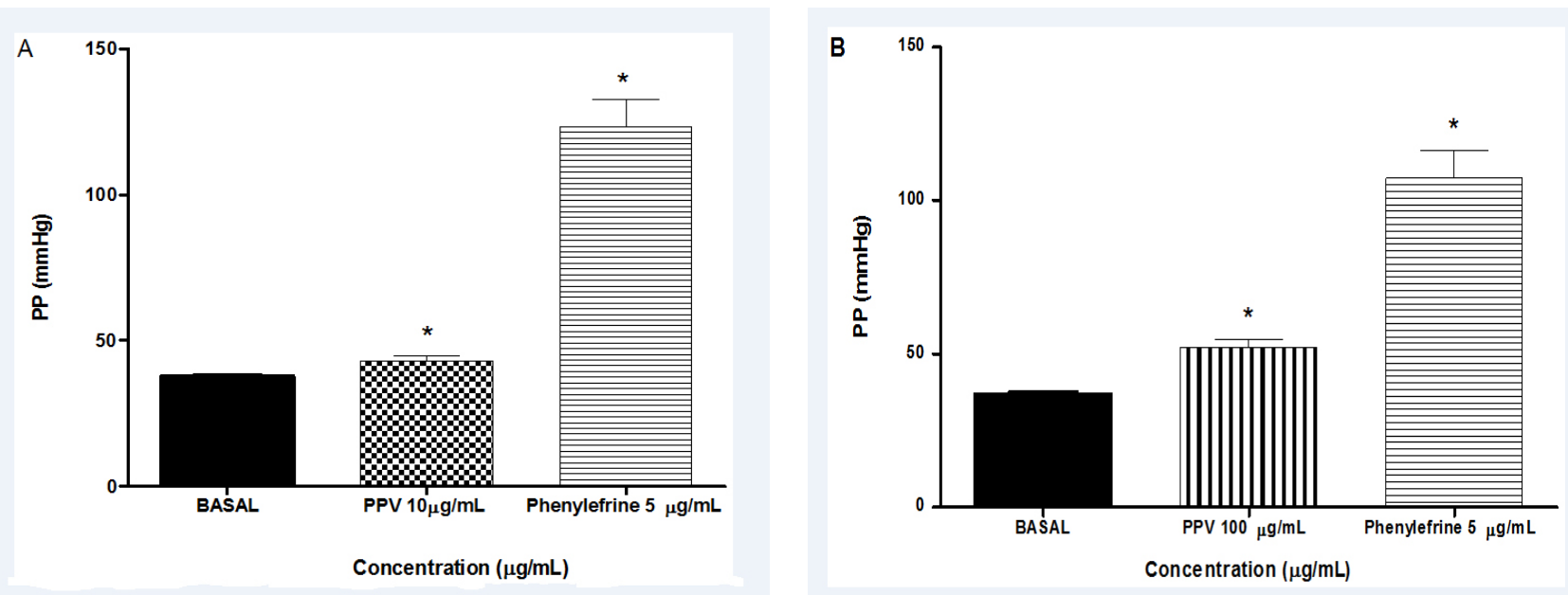

Figure 4. Effects of Polybia paulista venom (PPV) at concentrations of (A) $10 \mu \mathrm{g} / \mathrm{mL}$ and (B) $100 \mu \mathrm{g} / \mathrm{mL}$ on perfusion pressure (PP) of arteriolar mesenteric beds. ${ }^{*} p<0.05$ compared with basal pressure.
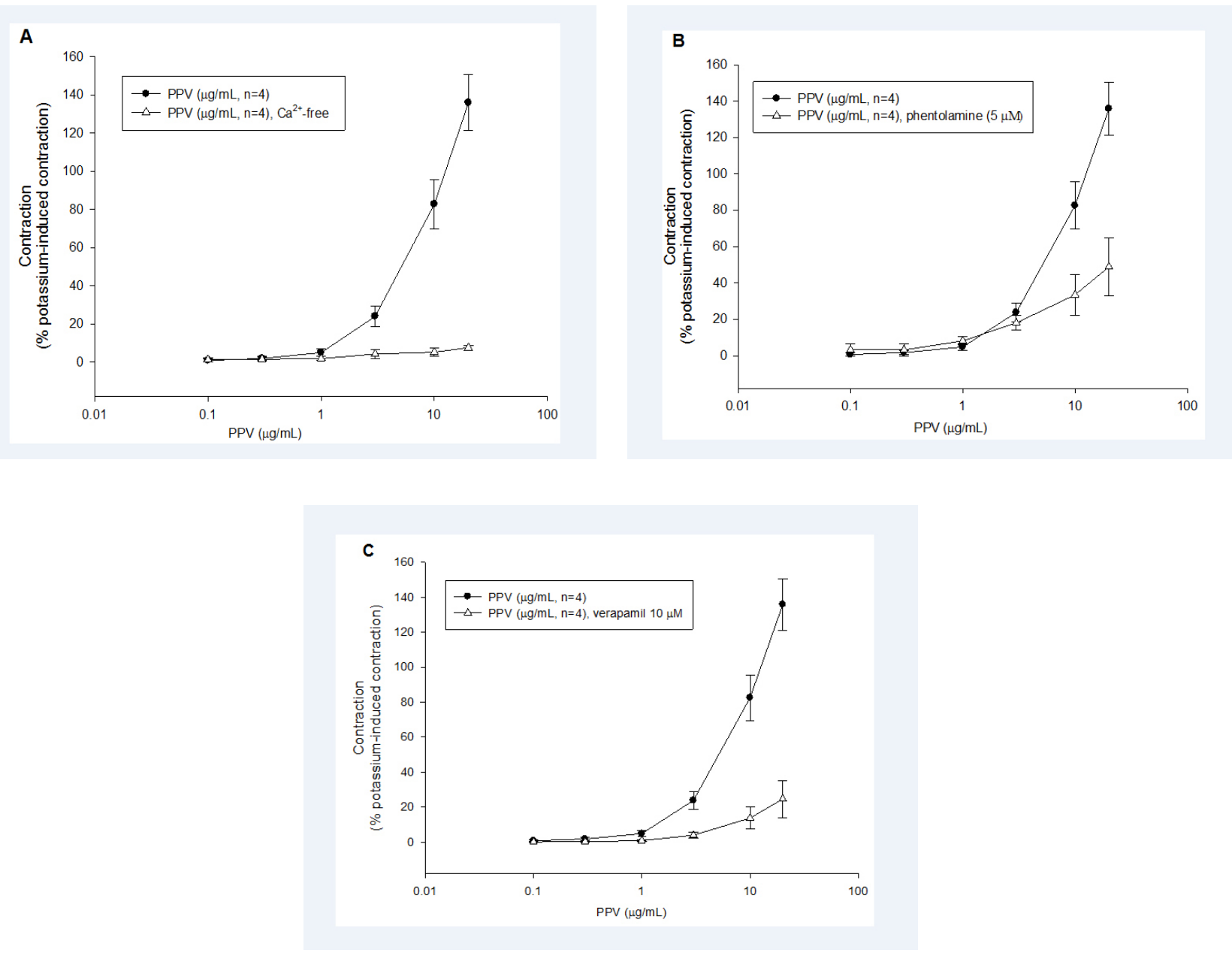

Figure 5. (A) Concentration response curve of Polybia paulista venom (PPV) in isolated aortic rings $(\bullet, n$ $=4 ; 0.1-20 \mu \mathrm{g} / \mathrm{mL})$, and venom with $C a^{2+}$-free medium $(\Delta, \mathrm{n}=4 ; 1 \mu \mathrm{M})$. (B) Concentration-response curve of PPV in isolated aortic rings $(\bullet, n=4 ; 0.1-20 \mu \mathrm{g} / \mathrm{mL})$ and venom with phentolamine $(\Delta, \mathrm{n}=4 ; 5 \mu \mathrm{M})$. (C) Concentration-response curve of PPV on potassium-induced $\left(\mathrm{K}^{+}, 60 \mathrm{mM}\right)$ contraction of isolated aortic rings $(\bullet, n=4 ; 0.1-20 \mu \mathrm{g} / \mathrm{mL})$ and venom with verapamil $(\Delta, \mathrm{n}=4 ; 10 \mu \mathrm{M})$. Data are expressed as means \pm SEM, one-way ANOVA, post-test Holm-Sidak, ${ }^{*} \mathrm{p}<0.001$, compared with corresponding baseline values. 


\section{DISCUSSION}

The study of the biological effects of wasp venoms has gained scientific attention due to the involvement of these arthropods in stinging incidents with important clinical outcomes. In this regard, the major findings of the present study are that PPV markedly changed kidney function and promoted vasoconstrictor effects. Changes in kidney function include increase in renal parameters such as perfusion pressure, vascular resistance, glomerular filtration rate and urinary flow. Renal changes observed in this study corroborate earlier reports with other animal venoms which registered similar changes in renal function $(24,25)$.

Despite the yet unknown profile of toxicological actions elicited by PPV on kidney tissue, there is a general assumption that it may exert a direct nephrotoxic effect, which is involved in the development of acute renal failure eventually observed in patients attacked by wasps (9). Herein, we demonstrated that PPV induced mild focal acute tubular necrosis. In fact, tubulointerstitial nephritis and acute tubular necrosis are often observed in patients envenomed by wasps $(8,11-13)$. Moreover, cell viability and membrane integrity decreased when the survival of untreated cells was compared with the mean percentage of surviving MDCK cells under a given PPV concentration using the $\mathrm{LDH}$ assay. This fact indicates that such changes are involved in the underlying mechanisms for development of PPV-induced toxic actions. Since the loss of membrane integrity was followed by an increase in LDH activity, it was suggested that cell death is the result of necrosis, confirming the histological findings in kidneys perfused with venom. Although toxic effects of PPV on cultured cells were observed in the concentration ranging from 25 to $100 \mu \mathrm{g} / \mathrm{mL}$, the perfusion of isolated kidneys with PPV at $3 \mu \mathrm{g} / \mathrm{mL}$ resulted in slight changes in tubular function by means of decrease in the $\mathrm{Na}^{+}$tubular transport rate.

The ability of PPV to induce deposition of proteinaceous material in urinary and tubular spaces is noteworthy and may be due to its toxic effect on the barrier function of glomeruli. This hypothesis is corroborated by Grisotto et al. (26), who reported that protein leakage by kidney tubules was induced by bee venom. Another implication of the finding is a putative myotoxic effect induced by PPV. It was previously reported that rhabdomyolysis could occur following wasp envenomation by deleterious effects of mastoparans on muscle cells involving caspase signaling pathways and mitochondrial injury (15). Notwithstanding, whether or not such actions due to these polycationic peptides are involved in PPV-induced renal effects, further studies will tell.

A hallmark of PPV-elicited actions was the vasoconstrictor effect induced by the venom in vascular preparations. PPV increased perfusion pressure and vascular resistance in isolated mesenteric beds and contracted aortic rings in vitro in a concentration-dependent manner, effects that were comparable to classically known vasoactive agents such as phenylephrine and potassium. Vasoconstrictor actions of PPV are probably involved in the major functional changes observed after perfusion of isolated kidneys with PPV. The venom increased kidney perfusion pressure, renal vascular resistance, urinary flow and glomerular filtration rate. It is interesting to note that the renal effects of PPV were established 60 minutes after perfusion, but were sustained for up to 120 minutes. Such effects agree with the results observed in vascular tissues, because contractions induced by PPV in vessel preparations were tonic and reached a sustained plateau, which was then maintained over the course of tissue perfusion or in the presence of PPV in the bath chamber.

In order to investigate the underlying mechanisms involved in the contraction of vascular smooth muscle, aortic preparations were kept in $\mathrm{Ca}^{2+}$-free medium. Since under $\mathrm{Ca}^{2+}$-free conditions PPV did not induce contractile effects, we concluded that its vasoactive properties are dependent of a transmembrane $\mathrm{Ca}^{2+}$ influx from the extracellular milieu. It is well known that smooth muscle cells have a straight dependence on extracellular $\mathrm{Ca}^{+2}$ for contraction (27). Indeed, following the activation of specific receptors, excitatory substances such as neurotransmitters promote $\mathrm{Ca}^{2+}$ influx through membrane channels, increasing ionic intracellular levels to induce cellular events including force development in vascular smooth muscle (28). Likewise, verapamil, a voltage-gated $\mathrm{Ca}^{2+}$ channel blocker, reduced the magnitude of the contractile response provoked by PPV, confirming that $\mathrm{Ca}^{2+}$ influx is stimulated by PPV and at least part of the 
contractile response is mediated by the passage of $\mathrm{Ca}^{2+}$ ions through voltage-gated $\mathrm{Ca}^{2+}$ channels. Additionally, phentolamine decreased the contractile behavior of aortic rings, indicating the involvement of $\alpha$-adrenergic receptors in PPVinduced contractile effects, an issue that deserves further investigation.

In conclusion, Polybia paulista wasp venom produced nephrotoxicity, which suggests a direct effect on cellular death through necrosis in renal tubular cells. The contractile vascular effect, which involves calcium influx through voltage-gated channels, is probably regulated by adrenergic pathways.

\section{ACKNOWLEDGEMENTS}

The authors thank Aline Falcão for the technical assistance, and The National Council for Scientific and Technological Development (CNPq) and The Cearense Foundation for Supporting Scientific and Technological Development (FUNCAP) for supporting the research.

\section{COPYRIGHT}

(C) CEVAP 2011

\section{SUBMISSION STATUS}

Received: February 7, 2011.

Accepted: April 1, 2011.

Abstract published online: April 6, 2011.

Full paper published online: May 31, 2011.

\section{CONFLICTS OF INTEREST}

There is no conflict.

\section{FINANCIAL SOURCE}

$\mathrm{CNPq}$ and FUNCAP provided the financial grants.

\section{ETHICS COMMITTEE APPROVAL}

All experiments were in accordance with the guidelines for the ethical use of experimental animals published by the Brazilian College on Experimental Animal Care (COBEA). Moreover, the present study was approved by the Institutional Animal Care Committee at Federal University of Ceará (protocol number 17/09).

\section{CORRESPONDENCE TO}

ALICE MARIA COSTA MARTINS NUNES, Departamento de Análises Clínicas e Toxicológicas, Universidade Federal do Ceará,
Fortaleza, CE, 60.420-970, Brasil. Phone: +55 853366 8263. Fax: +55 853366 8292. Email: martinsalice@gmail.com.

\section{REFERENCES}

1. Santos LD, Santos KS, de Souza BM, Arcuri HA, Cunha-Neto E, Castro FM, et al. Purification, sequencing and structural characterization of the phospholipase $\mathrm{A}_{1}$ from the venom of the social wasp Polybia paulista (Hymenoptera, Vespidae). Toxicon. 2007; 50(7):923-37.

2. Brigatte P, Cury Y, de Sousa BM, Baptista-Saidemberg NB, Saidemberg DM, Gutierrez VP, et al. Hyperalgesic and edematogenic effects of peptides isolated from the venoms of honeybee (Apis mellifera) and neotropical social wasp (Polybia paulista and Protonectarina sylveirae). Amino Acids. 2011;40(1):101-11.

3. Nakajima T, Yasuhara T, Uzu S, Wakamatsu T, Miyazawa T, Fukuda D, et al. Wasp venom peptides; wasp kinins, new cytotrophic peptide families and their physico-chemical properties. Peptides. 1985;6 Suppl 3:425-30.

4. de Oliveira MR, Palma MS. Polybitoxins: a group of phospholipases $\mathrm{A}_{2}$ from the venom of the neotropical social wasp paulistinha ( Polybia paulista). Toxicon. 1998; 36(1):189-99.

5. Hoffman DR. Hymenoptera venom allergens. Clin Rev Allergy Immunol. 2006; 30(2):109-28.

6. King TP, Valentine MD. Allergens of hymenopteran venoms. Clin Rev Allergy. 1987; 5(2):137-48.

7. França FO, Benvenuti LA, Fan HW, Dos Santos, DR, Hain SH, Picchi-Martins FR, et al. Severe and fatal mass attacks by "killer" bees (Africanized honey bess Apis mellifera scutellata) in Brazil: clinicopathological studies with measurement of serum venom concentrations. Q J Med. 1994;87(5):269-82.

8. Das RN, Mukherjee K. Asian wasp envenomation and acute renal failure: a report of two cases. McGill J Med. 2008;11(1):25-8.

9. Sakhuja V, Bhalla A, Pereira BJ, Kapoor MM, Bhusnurmath SR, Chugh KS. Acute renal failure following multiple hornet stings. Nephron. 1988;49(4):319-21.

10. Sitprija V, Boonpucknavig V. Renal failure and myonecrosis following wasp-stings. Lancet. 1972;1(7753):749-50.

11. Zhang R, Meleg-Smith S, Batuman V. Acute tubulointerstitial nephritis after wasp stings. Am J Kidney Dis. 2001;38(6):E33.

12. Vikrant S, Pandey D, Machhan P, Gupta D, Kaushal SS, Grover N. Wasp envenomation-induced acute renal failure: a report of three cases. Nephrology (Carlton). 2005;10(6):548-52.

13. Singh LR, Singh YT, Singh S, Singh NSK, Sharma LR. Acute renal failure in a child following multiple wasp stings. Indian J Nephrol. 2005;15(1):95-7.

14. D'Cruz S, Chauhan S, Singh R, Sachdev A, Lehl S. Wasp sting associated with type 1 renal tubular acidosis. Nephrol Dial Transplant. 2008;23(5):1754-5. 
15. Rocha T, de Barros LL, Fontana K, de Souza BM, Palma MS, da Cruz-Höfling MA. Inflammation and apoptosis induced by mastoparan Polybia-MPII on skeletal muscle. Toxicon. 2010;55(7):1213-21.

16. Bowman RH. Gluconeogenesis in the isolated rat kidney. J Biol Chem. 1970; 245(7):1604-12.

17. Fonteles MC, Cohen JJ, Black AJ, Wertheim SJ. Support of kidney function by long-chain fatty acids derived from renal tissue. Am J Physiol. 1983;244(3):235-46.

18. Walser M, Davidson DG, Orloff J. The renal clearance of alkali-stable inulin. J Clin Invest. 1955;34(10):15203.

19. Pitts RF. Metabolism of amino acids by the perfused rat kidney. Am J Physiol. 1971;220(4):862-7.

20. Martinez-Maldonado M, Opava-Stitzer R. Free water clearance curves during saline, mannitol, glucose and urea diuresis in the rat. J Physiol. 1978;280(1):487-97.

21. Chaim OM. Estudo da atividade citotóxica da proteína dermonecrótica do veneno da aranha marrom (L. intermedia) com ênfase no efeito nefrotóxico [dissertation]. Curitiba, PR: Universidade Federal do Paraná; 2005.

22. Liu Y, Peterson DA, Kimura H, Schubert D. Mechanism of cellular 3-(4,5-dimethylthiazol-2-yl)2,5-diphenyltetrazolium bromide (MTT) reduction. J Neurochem. 1997;69(2):581-93.
23. McGregor DD. The effect of sympathetic nerve stimulation on vasoconstrictor responses in perfused mesenteric blood vessels of the rat. J Physiol. 1965;177(1): 21-30.

24. de Sousa Alves R, do Nascimento NR, Barbosa PS, Kerntopf MR, Lessa LM, de Sousa CM, et al. Renal effects and vascular reactivity induced by Tityus serrulatus venom. Toxicon. 2005;46(3):271-6.

25. Martins AMC, Barbosa PSF, Sousa DF, Alves CD, Menezes DB, Lima C, et al. Antivenom action on renal effects induced by Thalassophryne nattereri venom. J Venom Anim Toxins incl Trop Dis. 2009;15(1):125-35.

26. Grisotto LS, Mendes GE, Castro I, Baptista MA, Alves VA, Yu L, et al. Mechanisms of bee venom-induced acute renal failure. Toxicon. 2006;48(1):44-54.

27. Somlyo AP, Somlyo AV. Signal transduction through the RhoA/Rho-kinase pathway in smooth muscle. J Muscle Res Cell Motil. 2004;25(8):613-5.

28. Jackson WF. Ion channels and vascular tone. Hypertension. 2000;35(1 Pt 2):173-8. 